\title{
Nitrogen balance in a hilly semi-agricultural watershed in Northern Italy
}

\author{
Linda Pieri, Francesca Ventura, Marco Vignudelli, Paola Rossi \\ Department of Agroenvironmental Sciences and Technologies, University of Bologna, Italy
}

\begin{abstract}
The research was carried out for 7 years, $1998-2005$, in a semi-agricultural watershed, called Centonara, set within a natural regional park and situated in the hills surrounding Bologna, northern Italy. This area is characterized by one of the most interesting badlands complexes in Europe and represents one of the main points of naturalistic interest. The watershed is partially cultivated (about $30 \%$ of the total area) with arable crops, mostly cereals and alfalfa. To evaluate the impact of agricultural activity on the eco-sustainability of this area, the nitrogen $(\mathrm{N})$ balance was computed. Although it is only an estimation of the potential environmental damage, the nitrogen balance is a useful indicator of the risk posed to the environment from excessive nitrogen and can be useful to understand the possible effects of a certain type of agricultural and environmental management and policy. The balance was calculated by computing the difference between all inputs and all outputs. The nitrogen balance of the watershed was found to be sustainable, with an annual nitrogen balance ranging between -2.3 and $+4.4 \mathrm{~kg} \mathrm{ha}^{-1}$. Despite the limited presence of arable lands, the agricultural management played the main role in determining the sustainability of the watershed, strongly influencing both the principal $\mathrm{N}$ sources and sinks. In fact, major $\mathrm{N}$ inputs derived from inorganic fertilization (8.1-15.5 $\left.\mathrm{kg} \mathrm{ha}^{-1} \mathrm{yr}^{-1}\right)$ and biological fixation $(8.3-14.3 \mathrm{~kg}$ ha $\left.^{-1} \mathrm{yr}^{-1}\right)$. On the other hand, plant removal constituted the most important output (17.7-25.6 $\left.\mathrm{kg} \mathrm{ha}^{-1} \mathrm{yr}^{-1}\right)$. $\mathrm{N}$ losses in the drainage water were limited (3.0-9.5 $\left.\mathrm{kg} \mathrm{ha}^{-1} \mathrm{yr}^{-1}\right)$ and the Centonara stream
\end{abstract}

Correspondence: Francesca Ventura, Department of Agroenvironmental Sciences and Technologies, University of Bologna, viale Fanin 44, 40127 Bologna, Italy.

Tel. +39.051.2096693 Fax: +39.051 .2096241$

E-mail: francesca.ventura@unibo.it

Key words: agriculture, eco-sustainability, nitrogen balance, nitrogen losses, watershed.

Acknowledgements: the study was conducted under major financial support of the Fondazione Cassa di Risparmio in Bologna. We thank N.Gaspari for his valuable technical help.

Received for publication: 10 September 2010.

Accepted for publication: 8 January 20011.

(C) Copyright L. Pieri et al., 2011

Licensee PAGEPress, Italy

Italian Journal of Agronomy 2011; 6:e12

doi:10.4081/ija.2011.e12

This article is distributed under the terms of the Creative Commons Attribution Noncommercial License (by-nc 3.0) which permits any noncommercial use, distribution, and reproduction in any medium, provided the original author(s) and source are credited. water was found to be unpolluted, with a nitrate concentration always below the EU limit for drinking water. The similar magnitude of total $\mathrm{N}$ inputs and outputs indicated that the crop management, especially the crop rotation and the $\mathrm{N}$ fertilization, in the Centonara watershed has reached a good level of ecological sustainability. Finally, the computation of the $\mathrm{N}$ fertilizer-use efficiency index resulted to be useful to identify which crop and which type of management (organic or conventional) were more suitable for the pedo-climatic condition of the studied area.

\section{Introduction}

Water quality is strongly affected, directly or indirectly, by agricultural activity, due to both macro- and microscale factors. While the macroscale factors, such as climate, landscape topography and parent material, characterize the ecosystems and establish the agricultural peculiarities, the microscale factors, such as land use and the management at watershed scale, control the agricultural functioning.

Bad agricultural management produces degradation of the soil quality, with impacts on water quality through leaching of excess nutrients and pesticides into surface and underground waters (Zalidis et al., 2002). In particular, the accumulation of nitrogen in an ecosystem can cause a serious alteration of the natural cycle, with consequences to terrestrial and marine environments. In several cases, the nitrogen surplus is due to the asynchrony between the availability of fertilizers and the crop needs, and the excessive application of nitrogen fertilizers may lead to losses of nitrates into shallow groundwater (Addiscott et al., 1991). Since the 70's, risks on natural environments connected to the abuse of nitrogen in agriculture have been well known and, through the Nitrates Directive (91/676/EEC) the EU tried to reduce water pollution caused by nitrates from agricultural activities. This action, together with the diffusion of organic cultivation and the government controls, has produced a better and more punctual usage of fertilizers, as resulted from the European Environmental Agency (EEA) assessment (OECD, 2003), which indicates that in 2000 the nitrogen balance at EU-15 level was $55 \mathrm{~kg} \mathrm{ha}^{-1}$, with a general decline of $16 \%$ compared to that of 1990, apart from in Ireland and Spain where an increase was registered. This result was due to a decrease in not wellspecified input rates $(-1.0 \%)$ and a significant increase in nitrogen losses (10\%). Among the EU-15, Italy was the State with the lowest nitrogen surplus, $37 \mathrm{~kg} \mathrm{ha}^{-1}$, but also the other Mediterranean countries, such as France and Spain, had a similar balance, probably on account of the lower livestock production in this part of Europe.

Unfortunately, the national balance may hide important local differences, due to microscale factors, determining the actual nitrogen leaching risk at regional or local scale. Individual Member States can thus have an acceptable nitrogen balance at a national level, but significant and diverse experiences of nitrogen pollution at regional or local scales. European researches at watershed scale report a wide variability of yearly $\mathrm{N}$ balance, from less than $10 \mathrm{~kg} \mathrm{ha}^{-1}$ (Beaudoin $e t$ al., 2005) to more than $100 \mathrm{~kg} \mathrm{ha}^{-1}$ (Bechmann et al., 1998), while 
Ventura et al. (2008) find a negative balance $\left(-7.6 \mathrm{~kg} \mathrm{ha}^{-1}\right)$. These results indicate that, because of the unique characteristics and agricultural peculiarities of each site and the various purposes and approaches for calculating the nutrient balance, caution should be used whenever results are compared with literature data. However, at watershed or national scales, computation of $\mathrm{N}$ balance is one of the potentially useful methods for predicting the risk of nitrate leaching into groundwater and superficial water bodies and the potential nitrogen surplus is currently the best available approximation of agricultural pressures on water quality. Since agriculture influences the natural N cycling attending to all the balance components (i.e. high nitrate accumulation and the flow of water into the soil profile are pre-conditions for nitrate leaching in a plain area, while a soil with vegetation coverage reduces the raindrop impact, favouring the water infiltration into the soil and limiting the superficial runoff, the most important nitrogen conveyance in sloping area), the eradication of $\mathrm{N}$ contamination of the water systems requires a comprehensive understanding of how $\mathrm{N}$ is processed in agricultural systems. The objective of this research was to test the ecological sustainability, defined as the maintenance of the global ecosystem, of a hilly semi-agricultural watershed in the Emilia Romagna region, by quantifying the local nitrogen balance. The eco-sustainability of this area is, in fact, very important because it is one of the main points of naturalistic interest in Italy, rich in biodiversity and ecosystems. Furthermore, the computation of the nitrogen balance at watershed scale is particularly valuable to identify the microscale factors, such as land use and management, which take part in the detemination of the nitrogen balance, and the relative importance of different sources of $\mathrm{N}$ inputs and outputs.

\section{Materials and Methods}

\section{Site description}

The Centonara watershed is located in the Bologna province ( $44^{\circ} 28^{\prime}$ $\mathrm{N}, 11^{\circ} 28^{\prime} \mathrm{E}$ ), in Northern Italy, on the first hills of the Apennines. It is within a regional natural park called Parco Regionale dei Gessi e Calanchi dell'Abbadessa, one of the most interesting geo-morphological features complexes (badlands) in Europe, where rock exposures, ecosystems, landscapes, species and botanical associations, habitats and staging points for fauna - all typical of the regional territory - are safeguarded (Antonioli and Cazzola, 1999). Recently, the area has also started to play an active role in scientific research, in environmental education, in the conservation and maintenance of the local ecological balance, in the recovery and valorization of the historical heritage and in the promotion of environmental values, with a view to tourism.

The watershed has a total area of 275 ha, 197 ha of which is monitored, most of it belonging to the University of Bologna (Figure 1). It is hydrologically isolated and the Centonara stream, which collects the drainage water, is characterized by seasonal flow, very scarce or null during the summer. Natural riparian buffers flank the Centonara.

The elevation ranges between 84 and $350 \mathrm{~m}$ a.s.l, with main slopes of $25-35 \%$. The geology is a fresh alluvial deposition of the upper Pleistocene, with undifferentiated clay moraine and recent, yellow sand. Soils developed on this parent material are Inceptisols and Vertisols. The geological settings of the area create stratigraphic discontinuities (Farabegoli et al., 1994), potentially facilitating local perched water tables (Pieri et al., 2007). The soil texture is heterogeneous and the textural classes are represented in Figure 1c.

The watershed is characterized by a temperate Mediterranean climate (Köppen-Geiger classification), where the highest and lowest temperatures occur in July-August and December-January respectively and the annual average precipitation is $750 \mathrm{~mm}$ (over a 15-year peri-
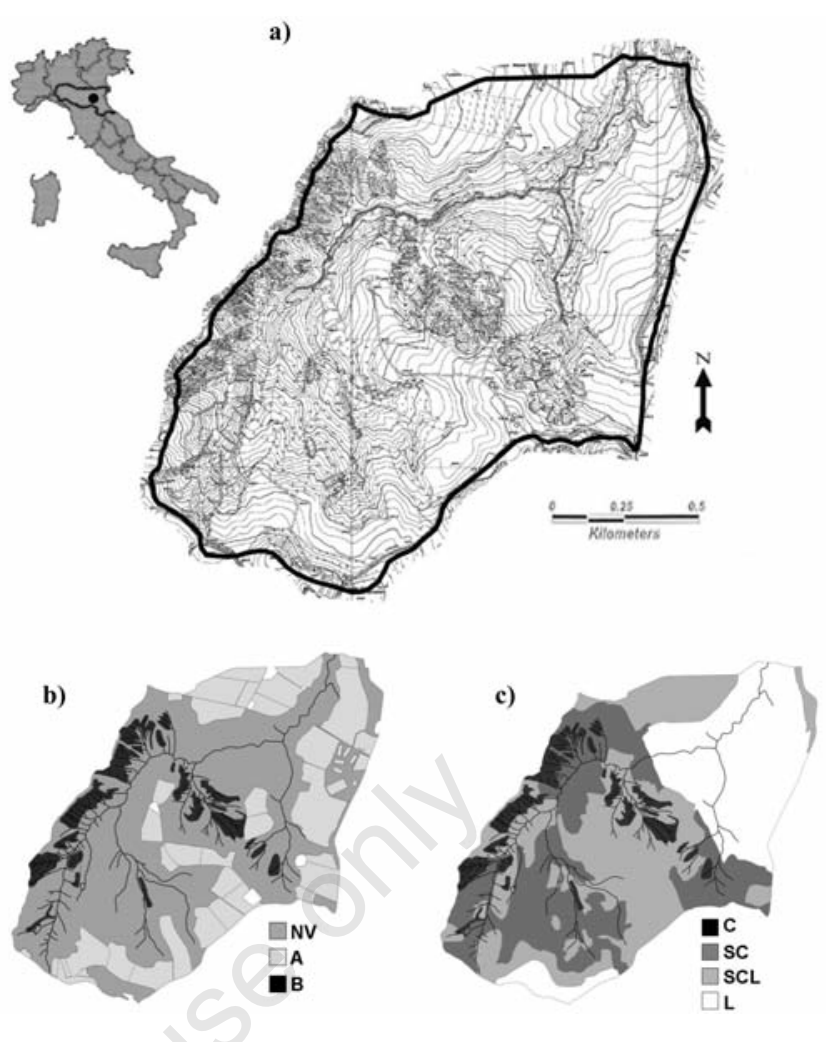

Figure 1. Centonara watershed: map location and slopes. (a) land use. (b) A, agricultural land; NV, natural vegetation; B, badlands; soil texture. (c) C, clay; SC, silty clay; SCL, silty clay loam; L, loam.

od), concentrated in two rainy seasons, spring and autumn. Despite this, during the summer, some intensive thunderstorms can occur and produce runoff events (Ventura at al., 2004).

Regarding the land use, the watershed could be subdivided in three large areas: $30 \%$ cultivated area, $60 \%$ area with spontaneous vegetation and $10 \%$ area with badlands (Figure $1 \mathrm{~b}$ ).

The arable lands are prevalently cultivated with arable crops, such as alfalfa and cereals, especially wheat, barley and sorghum. Over the trial duration, 1998-2005, part of this area was occupied by a private organic farm and, starting from 2001-02, also some fields belonging to the University were destined to organic cultivation: organic wheat, barley and sorghum together occupied almost $20 \%$ of the cultivated area in 2001-02. In these fields no synthetic pesticides and fertilizers were applied and nitrogen was introduced with organic fertilizers. The soil used for agricultural activity has a mean slope of $15 \%$.

The rest of the watershed is characterized by very relevant slopes and it is occupied by various types of spontaneous vegetation and badlands. The soil occupied by badlands is almost totally bare and in that area slopes range between $35-65 \%$.

Since no industrial and urban areas are present in the watershed (the nearest industrial area is $6 \mathrm{~km}$ away and two busy roads are 2 and $5 \mathrm{~km}$ downhill from the monitored area), it was supposed that the chemical composition of the Centonara stream water derives mainly from the agricultural activity.

\section{Records and information collections}

Throughout the trial, the watershed was monitored by means of interviews to all the farmers (3), recording all the information regarding land use, tillage and management: in particular, information was collected twice per year about sowing, tillage operations, fertilizations, 
herbicide applications and yields. The data can be considered reliable not only because most of the monitored area was managed by staff of the University of Bologna but also because it was seen to be comparable with the information issued in the official statistics for the Bologna district.

The watershed was equipped with an agro-meteorological station that provided records of the main meteorological elements: rainfall quantity and intensity, relative humidity, air temperatures, wind direction and velocity and solar radiation. Weekly, a rainfall sample was collected by means of a rain gauge and stored to be analysed.

The Centonara stream was continuously monitored by means of a sampling and measurement station. The station is comprehensive of an automatic sampler that collects samples of water from the stream and pipes them into polypropylene bottles stored in a refrigerator (to avoid nitrate microbiological degradation). An ultrasonic sound waves module, fixed on the bottom of the canal, provides the measure of level and velocity of water.

\section{Nitrogen balance calculation}

The nitrogen balance was calculated following the simplest deterministic approach of Howarth et al. (1996). This method provides a static accounting of the input and output components, taking into account the main fluxes of materials entering and leaving the watershed. The balance, surplus or deficit, is a measure of enrichment (output < input) or of the net depletion (output > input) of the system (Watson and Atkinson, 1999; Oenema et al., 2003; Oenema and Heinen, 1999).

More precisely, the following equation was computed:

$\Delta \mathrm{N}=$ input components - output components

$\Delta \mathrm{N}=\left(\mathrm{N}_{\mathrm{F}}+\mathrm{N}_{0}+\mathrm{N}_{\mathrm{AD}}+\mathrm{N}_{\mathrm{SF}}+\mathrm{N}_{\mathrm{C}}+\mathrm{N}_{\mathrm{E}}\right)-\left(\mathrm{N}_{\mathrm{PR}}+\mathrm{N}_{\mathrm{DW}}+\mathrm{N}_{\mathrm{D}}+\mathrm{N}_{\mathrm{V}}\right)$.

where:

$\Delta \mathrm{N}=$ nitrogen variation

$\mathrm{N}_{\mathrm{F}}=$ nitrogen mineral fertilizer

$\mathrm{N}_{0}=$ nitrogen organic fertilizer

$\mathrm{N}_{\mathrm{AD}}=\mathrm{N}$ from atmospheric deposition

$\mathrm{N}_{\mathrm{SF}}=$ symbiotic $\mathrm{N}$ fixation

$\mathrm{N}_{\mathrm{C}}=\mathrm{N}$ from crop residue combustion

$\mathrm{N}_{\mathrm{E}}=\mathrm{N}$ from excrement of animals

$\mathrm{N}_{\mathrm{PR}}=$ plant removal

$\mathrm{N}_{\text {DW }}=$ losses in drainage water

$\mathrm{N}_{\mathrm{D}}=$ denitrification losses

$\mathrm{N}_{\mathrm{V}}=\mathrm{NH}_{3}$ volatilization

All terms were in $\mathrm{kg} \mathrm{N} \mathrm{ha}^{-1} \mathrm{yr}^{-1}$.

The watershed was divided in three sub-areas, depending on their characteristics, namely cultivated, badlands and natural vegetation (Figure 1b). The balance was evaluated differently in each case: in the cultivated area all the balance components were determined, using actual measurements, farmers' interviews and estimations from available data, mean literature values and regional statistics database. While residues, if present, were removed immediately after the harvest, the NC component was negligible and was not taken into account.

The natural vegetation area, all along covered by spontaneous vegetation, was treated as an ecosystem, where the different $\mathrm{N}$ pools (organic and mineral) and the transformation between the diverse $\mathrm{N}$ forms (i.e., immobilization and mineralization) were considered in equilibrium. № balance inputs and outputs were taken into account. In the badland area no direct anthropic action occurs too. For the $\mathrm{N}$ balance, only the atmospheric deposition was took into account; in fact, because this area presents clay soil (Figure 1c), no vegetation at all and elevate slopes (35-65\%), after rainfall events, runoff is frequent and highly probably.

\section{Nitrogen input}

Inorganic and organic nitrogenous fertilizers

Data on N fertilizer use were obtained from farmers' interviews. They provided information about crop yields and management of crop residues, type of fertilizer, dose and date of distribution. In particular, knowing the type of fertilizer was important to evaluate the losses via volatilization, as explained after.

The total amount of $\mathrm{N}$ applied to each crop was computed as the sum of the $\mathrm{N}$ applied in all the fertilizer applications for each crop and it was divided into inorganic and organic fertilizers. During the first two years, part of the cultivated fields was fertilized with horses manure. For the horse excreta an $\mathrm{N}$ content of $0.5 \%$ was considered.

\section{Atmospheric deposition}

Samples of bulk deposition (wet plus dry deposition) were collected to determine the concentration of $\mathrm{NO}_{3}{ }^{-}, \mathrm{NO}_{2}{ }^{-}$and $\mathrm{NH}_{4}{ }^{+}$, and then transformed into $\mathrm{N}$ concentration. The analyses were made using the capillary electrophoresis methods (Pieri et al., 2009). The atmospheric deposition was estimated by multiplying the $\mathrm{N}$ concentration for the rainfall amounts of each year, event per event.

The main source of $\mathrm{N}$ oxides is the combustion of fossil fuel (industries and motor vehicles), while agricultural activity constitutes the main source for ammonium. Nevertheless because these pollutants are gases, once they reach the atmosphere they can be transported far away with air masses (Balestrini et al. 2000) and, consequently, these ions can even be found in the atmospheric depositions of natural areas far from N sources.

\section{Agricultural biological nitrogen fixation}

Nitrogen is also introduced into the agro-farming system through $\mathrm{N}$ fixation, due to the symbiotic bacteria Rhizobium. Its quantity varies with the surface cultivated with legume crops and the plant species. The N-fixation coefficients was estimated through the model proposed by Høgh-Jensen et al. (2004), which also considers the amount of $\mathrm{N}$ accumulated belowground and allow a locality-specific parametrization of user defined parameters. The model adapted to our condition is the following:

$\mathrm{N}_{\mathrm{SF}}=\mathrm{DM}_{\text {legume }} * \mathrm{~N} \% * \mathrm{P}_{\text {fix }} *\left(1+\mathrm{P}_{\text {rott+stubble }}+\mathrm{P}_{\text {immobile }}\right)$

where

$\mathrm{DM}_{\text {legume }}=$ accumulated amount of legume shoot dry matter;

$\mathrm{N} \%$ = concentration of $\mathrm{N}$ in the dry matter of the legume $\left(\mathrm{kg} \mathrm{kg}^{-1}\right)$;

$\mathrm{P}_{\text {fix }}=$ fixed $\mathrm{N}_{2}$ as proportion of total $\mathrm{N}$ in the shoot dry matter of the legume;

$\mathrm{P}_{\text {root+stubble }}=$ fixed $\mathrm{N}_{2}$ in the root and stubble as proportion of totally fixed shoot $\mathrm{N}$ at the end of the growing period;

$\mathrm{P}_{\text {immobile }}=$ fixed $\mathrm{N}_{2}$ immobilised in an organic soil pool at the end of the growing period as proportion of fixed shoot $\mathrm{N}$ at the end of the growing period.

For the parametrization of the model, values of $\mathrm{N}$ concentration in dry matter and the proportion of the $\mathrm{N}$ in the legume that derived from the atmosphere were derived from Tabacco et al. (2003), obtained in the Padana Plain, using the $15 \mathrm{~N}$ isotope dilution technique. Because no parameters were found for the field bean, value of biological fixation found in the literature (Vance, 1998) was used $\left(150 \mathrm{~kg} \mathrm{ha}^{-1}\right)$. To quantify the total $\mathrm{N}$ fixation, the areas with legumes were multiplied by the specific $\mathrm{N}$ fixation rate.

\section{Nitrogen output}

\section{Nitrogen plant removal}

Nitrogen plant removal was quantified by multiplying the total yield of each crop by their $\mathrm{N}$ concentration obtained by regional database, 
specific for that crop and part of plant, such as grain, straw, root, stover, etc. (Regione Lombardia-PSR 2003; Regione Campania-DGR 2302/2003). The plant removal values are listed in Table 1. The total yields were provided by farmers and, for the few missing data, the average of the typical yields for that area were used. All crop residues were left on the fields, expect for the straw that was a saleable product. Apart from the straw, $\mathrm{N}$ in crop residues was not accounted as output in the balance, while was considered to return to the soil.

Table 1. Nitrogen plant removal coefficients and mean yield.

\begin{tabular}{|c|c|c|c|}
\hline Crop & & $\begin{array}{c}\text { Plant removal } \\
\left(\mathrm{kg} \mathrm{t}^{-1}\right)\end{array}$ & 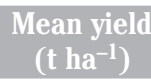 \\
\hline Alfalfa & hay & 25 & 8.0 \\
\hline Barley & $\begin{array}{l}\text { grain } \\
\text { straw }\end{array}$ & $\begin{array}{c}18 \\
5\end{array}$ & $\begin{array}{l}5.0 \\
3.5 \\
\end{array}$ \\
\hline Corn & $\begin{array}{l}\text { grain } \\
\text { stover }\end{array}$ & $\begin{array}{c}18 \\
6\end{array}$ & $\begin{array}{l}7.0 \\
7.0\end{array}$ \\
\hline Forage & hay & 26 & 6.0 \\
\hline Organic barley & $\begin{array}{l}\text { grain } \\
\text { straw }\end{array}$ & $\begin{array}{l}18 \\
5\end{array}$ & $\begin{array}{l}3.5 \\
2.0\end{array}$ \\
\hline Field bean & plant & 20 & 1.1 \\
\hline Organic sorghum & $\begin{array}{l}\text { grain } \\
\text { stover }\end{array}$ & $\begin{array}{l}15 \\
6.5\end{array}$ & $\begin{array}{l}5.0 \\
4.0\end{array}$ \\
\hline Organic wheat & $\begin{array}{l}\text { grain } \\
\text { straw }\end{array}$ & $\begin{array}{c}23 \\
6 \\
\end{array}$ & $\begin{array}{l}3.2 \\
2.0\end{array}$ \\
\hline $\begin{array}{l}\text { Set-aside } \\
\text { Sorghum }\end{array}$ & $\begin{array}{c}\text { hay } \\
\text { grain } \\
\text { stover }\end{array}$ & $\begin{array}{l}27 \\
15 \\
6.5\end{array}$ & $\begin{array}{l}4.5 \\
7.0 \\
6.0\end{array}$ \\
\hline Sugar beet & $\begin{array}{l}\text { root } \\
\text { leaves }\end{array}$ & $\begin{array}{c}2 \\
3.5 \\
27\end{array}$ & $\begin{array}{l}45.0 \\
10.0 \\
18\end{array}$ \\
\hline Sunflower & plant & 27 & 1.8 \\
\hline $\begin{array}{l}\text { Switchgrass } \\
\text { Wheat }\end{array}$ & $\begin{array}{l}\text { plant } \\
\text { grain } \\
\text { straw }\end{array}$ & $\begin{array}{c}27 \\
23 \\
6\end{array}$ & $\begin{array}{c}12.0 \\
4.8 \\
3.5\end{array}$ \\
\hline
\end{tabular}

Table 2. Surface in ha and percentage of total watershed dedicated to crops cultivation, during the studied period.

\begin{tabular}{lccccccc}
\hline Crop & $1998-$ & $1999-$ & 2000 & $2001-$ & $2002-$ & $2003-$ & $2004-$ \\
& 99 & 00 & 01 & 02 & 02 & 04 & 05 \\
Alfalfa & 12.3 & 12.3 & 18.1 & 16.9 & 16.8 & 19.7 & 19.7 \\
Barley & - & - & - & - & - & 3.0 & - \\
\hline Corn & 0.5 & 0.5 & 0.5 & 0.5 & 0.5 & 0.5 & 0.5 \\
Field beans & - & - & 1.3 & 1.4 & 1.7 & - & - \\
\hline Mixed pasture & 6.1 & 7.5 & 9.6 & 5.8 & 5.6 & 5.8 & 5.8 \\
Orchard & 4.2 & 4.2 & 4.2 & 4.2 & 4.2 & 4.2 & 4.2 \\
\hline Organic barley & - & - & 1.4 & 3.0 & 0.8 & - & 1.0 \\
Organic sorghum & - & - & 1.4 & 4.7 & - & - & - \\
\hline Organic wheat & 4.2 & 2.9 & 2.9 & 4.1 & 2.2 & 1.7 & - \\
Set-aside & 13.1 & 3.2 & 1.8 & 1.3 & 10.5 & 9.1 & 10.5 \\
\hline Sorghum & 4.2 & - & - & - & - & - & - \\
Sugar beet & - & 5.4 & 2.7 & - & - & - & - \\
\hline Sunflower & - & 9.3 & - & 0.5 & 12.1 & - & 2.7 \\
Switchgrass & - & - & - & 5.4 & 5.4 & 5.4 & 5.5 \\
\hline Wheat & 15.3 & 14.5 & 14.8 & 12.1 & - & 9.1 & 9.3 \\
Total & 59.9 & 59.8 & 58.7 & 59.9 & 59.8 & 58.5 & 61.6 \\
\hline Percentage & & & & & & & \\
\hline
\end{tabular}

\section{Losses in drainage water}

To calculate the quantity of nitrogen losses in the drainage water, Centonara water samples were collected daily and then analysed to determine the nitrates concentration. This concentration was then multiplied by the discharge $\left(\mathrm{m}^{3}\right)$ of the stream and referred to one hectare of the surface.

\section{Denitrification of farmland}

Denitrification depends on several factors, such as the fertilizers composition and date of application, meteorological elements, like temperature and rainfall, and soil texture and structure. There are only few field measurements from southern Europe. To estimate $\mathrm{N}_{\mathrm{D}}$ we have used experimental data by Gamba et al. (1998) and Arcara et al. (1999), obtained in a precedent research carried out few kilometres far from our experimental site, and similar for soil and climatic condition. The annual denitrification flux is quantified in $4 \%$ of the total urea and nitrate ammonium administration, while the losses from manure were negligible.

\section{$\mathrm{NH}_{3}$ volatilization}

Nitrogen is lost in the atmosphere via $\mathrm{NH}_{3}$ volatilization from farmland, especially due to urea and other ammonium fertilizers and it becomes one of the major components of dry and wet deposition (Bao et al., 2006). Meisinger and Randall (1991) and Burkart and James (1999) found that $\mathrm{N}$ volatilization could be between 0 and $20 \%$ of the surface-applied urea and between 15 and $30 \%$ of the solid manure, depending on the pedo-climatic conditions. Considering soil pH and moisture, we followed Puckett et al. (1999) and Isidoro et al. (2006) and chose a mean loss of $10 \% \mathrm{~N}$ for applied urea and ammonia fertilizer and $35 \% \mathrm{~N}$ for applied manure.

\section{Statistical analysis}

To better understand the components with the main role in determining the final $\Delta \mathrm{N}$ and if other factors indirectly involved in the process (rainfall, percentage of crops on the watershed, percentage of legumes on the watershed, etc.) could influence the final results, the Pearson correlation matrix was computed, using the statistical package of the Microsoft Excel program.

\section{Results}

\section{Rainfall and discharge}

Annual precipitation presented a fairly large fluctuation ranging between $520 \mathrm{~mm}$ and $868 \mathrm{~mm}$ (Figure 2). The average annual rainfall

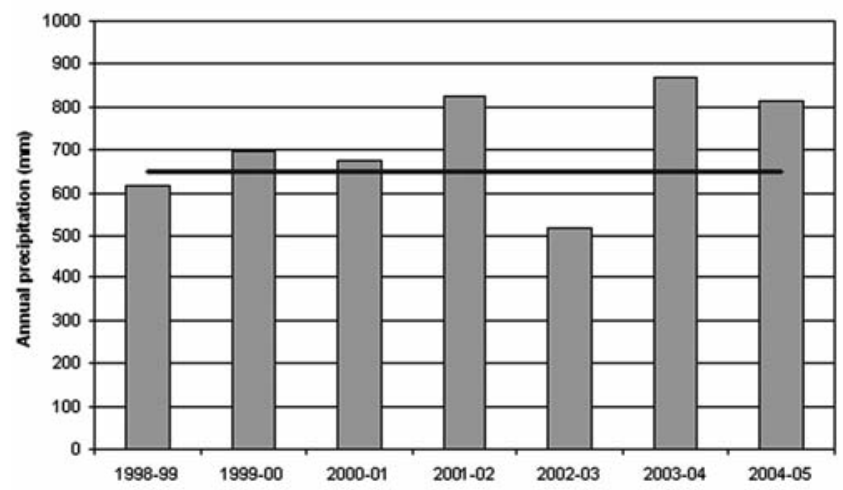

Figure 2. Annual precipitations. Climatological mean, $750 \mathrm{~mm}$; the line is the mean of the study period, $650 \mathrm{~mm}$ ). 
was $650 \mathrm{~mm}$. In spite of the different annual amounts, the yearly seasonal trends followed the typical distribution pattern of the climate, with most of the rainfall in autumn (November, September and October) and in spring (April) (Figure 3). The monthly Centonara flow (meanly about $650000 \mathrm{~m}^{3}$ ) was quite similar over the years, with an evident seasonal trend, reflecting the rainfall distribution pattern: during the summer, especially in June and July, the stream was almost dry (the mean monthly discharge for July was about $5500 \mathrm{~m}^{3}$ ), while it reached the highest values in autumn and winter, with $144,000 \mathrm{~m}^{3}$ in December, after the autumn precipitation. The stream flow reached a high level also in April $\left(71,000 \mathrm{~m}^{3}\right)$, due to the abundant spring rainfall.

\section{Land use and fertilizations}

Land use of the watershed was directly surveyed with field relieves. As described in Table 2, during the whole period, the cultivated area was about $30 \%$ of the watershed, while the rest of the surface was occupied by spontaneous vegetation (herbaceous, bushes and trees) and badlands. The crops in the watershed reflected the typical hilly cultivation of the Emilia-Romagna region: corn, tree plantation, mixed pasture, alfalfa and set-aside were always present, with diverse surfaces. For the studied period, corn plots and tree plantation had a fixed area

Table 3. Nitrogen fertilization $\left(\mathrm{kg} \mathrm{h}^{-1}\right)$ on the crops of the watershed during the study period.

\begin{tabular}{|c|c|c|c|c|c|c|c|c|}
\hline Crop & 1998- & 1999- & 2000 & 2001- & 2002- & $2003-$ & 2004 & Mean \\
\hline & 99 & 00 & 01 & 02 & 02 & & 05 & \\
\hline Barley & - & - & - & - & - & 60 & - & 60.0 \\
\hline Corn & 250 & 250 & 250 & 250 & 250 & 250 & 250 & 250.0 \\
\hline Field beans & - & - & 21 & $-\circ$ & $-{ }^{\circ}$ & - & - & 7.0 \\
\hline Mixed pasture & - & - & - & 30 & - & 31 & - & 30.5 \\
\hline Orchard & 163 & 163 & 163 & 163 & 163 & 163 & 109 & 155.3 \\
\hline Organic barley & - & - & 60 & 45 & 39 & - & 45 & 47.3 \\
\hline Organic wheat & 44 & 44 & 70 & 52 & 45 & 43 & - & 49.7 \\
\hline Organic sorghum & $n-$ & - & 60 & 40 & - & - & - & 50.0 \\
\hline Sorghum & 150 & - & - & - & - & - & - & 150.0 \\
\hline Sugar beet & - & 100 & 100 & - & - & - & - & 100.0 \\
\hline Sunflower & - & 100 & - & 120 & 120 & - & 115 & 113.8 \\
\hline Switchgrass & - & - & - & 40 & 40 & 40 & 46 & 41.5 \\
\hline Wheat & 100 & 100 & 100 & 100 & - & 120 & 115 & 105.8 \\
\hline
\end{tabular}

In 2001-02 and 2002-03 no fertilizers were applied on field beans.

Table 4. Yearly budget: the balance components are expressed in $\mathrm{kg} \mathrm{ha}^{-1}$.

\begin{tabular}{cccccccc}
\hline Year & $1998-$ & $1999-$ & 2000 & $2001-$ & $2002-$ & $2003-$ & $2004-$ \\
& 99 & 00 & 01 & 02 & 02 & 04 & 05 \\
Input & & & & & & & \\
$\mathrm{N}_{\mathrm{F}}$ & 11.6 & 15.5 & 9.5 & 8.1 & 9.1 & 8.1 & 8.9 \\
$\mathrm{~N}_{\mathrm{O}}$ & 2.0 & 1.7 & 2.4 & 3.7 & 1.0 & 1.7 & 0.5 \\
$\mathrm{~N}_{\mathrm{SF}}$ & 8.3 & 8.3 & 13.2 & 12.4 & 12.6 & 13.3 & 14.3 \\
$\mathrm{~N}_{\mathrm{AD}}$ & 6.4 & 7.2 & 7.0 & 8.5 & 5.4 & 8.9 & 8.4 \\
Total & 28.3 & 32.7 & 32.1 & 32.7 & 28.1 & 32.0 & 32.1 \\
Output & & & & & & & \\
$\mathrm{N}_{\mathrm{PR}}$ & 19.2 & 20.7 & 20.3 & 25.6 & 17.7 & 22.4 & 21.4 \\
$\mathrm{~N}_{\mathrm{DW}}$ & 3.0 & 6.3 & 5.1 & 6.9 & 9.5 & 8.0 & 9.4 \\
$\mathrm{~N}_{\mathrm{D}}$ & 0.5 & 0.6 & 0.4 & 0.3 & 0.4 & 0.3 & 0.4 \\
$\mathrm{~N}_{\mathrm{V}}$ & 1.9 & 2.1 & 1.8 & 2.1 & 1.3 & 1.4 & 1.1 \\
Total & 24.5 & 29.8 & 27.6 & 35.0 & 28.9 & 32.2 & 32.3 \\
\hline Balance & 3.8 & 2.9 & 4.4 & -2.3 & -0.7 & -0.1 & -0.1 \\
\hline
\end{tabular}

$\mathrm{N}_{\mathrm{F}}$, inorganic fertilizer; $\mathrm{N}_{\mathrm{O}}$, organic fertilizer; $\mathrm{N}_{\mathrm{FS}}$, symbiotic-fixation; $\mathrm{N}_{\mathrm{AD}}$, atmospheric deposition; $\mathrm{N}_{\mathrm{PR}}$, plant removal; $\mathrm{N}_{\mathrm{DW}}$, drainage water; $\mathrm{N}_{\mathrm{D}}$, denitrification; $\mathrm{NV} \mathrm{NH}_{3}$ volatilization. of 0.5 ha and 4.2 ha (3.7 ha of cherry tree wood and 0.5 ha of fertilized orchard) respectively. All the other crops were variously present, depending on the rotation (Table 2).

Total $\mathrm{N}$ fertilizer amounts, inorganic plus organic, for the major crops, are listed in Table 3 . Nitrogen applications were not subject to high variability: the fertilization amount of the organic wheat was the most varied, passing from $70 \mathrm{~kg} \mathrm{ha}^{-1}$ in $2000-01$ to $43 \mathrm{~kg} \mathrm{ha}^{-1}$ in 200304. For the organic sorghum and organic barley, the trend was a reduction in the fertilization amount: from $60 \mathrm{~kg} \mathrm{ha}^{-1}$ in $2000-01$ to $40 \mathrm{~kg}$ $\mathrm{ha}^{-1}$ in 2001-02 for the organic sorghum and from $60 \mathrm{~kg} \mathrm{ha}^{-1}$ in 200001 to $39 \mathrm{~kg} \mathrm{ha}^{-1}$ in 2002-03 for the organic barley. In the last year the amount for the orchard was notably reduced too, passing from $163 \mathrm{~kg}$ $\mathrm{ha}^{-1}$ to $109 \mathrm{~kg} \mathrm{ha}^{-1}$.

On a per hectare basis, major inputs by fertilizers were related to corn and orchard. In particular, corn was the crop receiving the highest fertilization regime, $250 \mathrm{~kg} \mathrm{ha}^{-1}$ of $\mathrm{N}$ from urea, while the orchard received on average $155 \mathrm{~kg} \mathrm{ha}^{-1}$ in manure. Indeed, these two cultivations did not greatly influence the nitrogen balance, as they only occu-

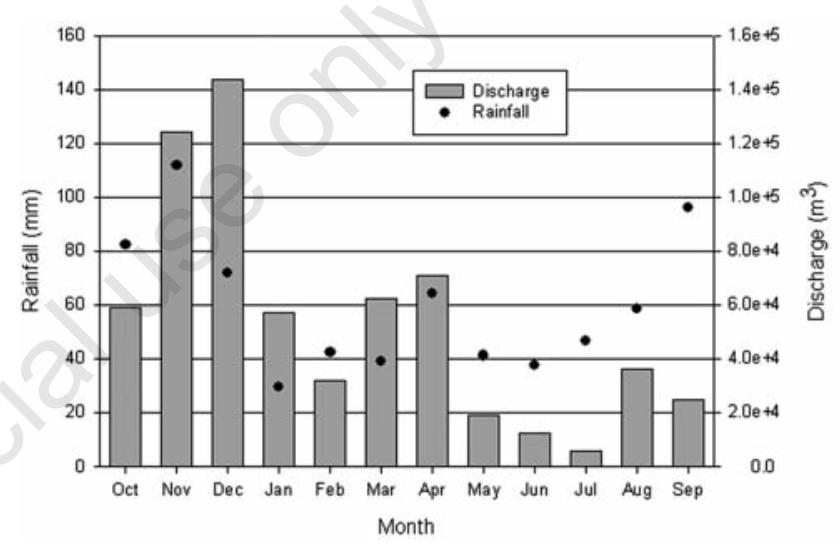

Figure 3. Mean monthly rainfall and discharge during the 7-yearlong study period.

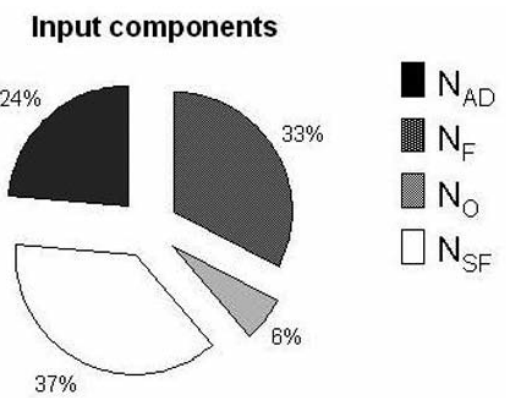

\section{Output components}

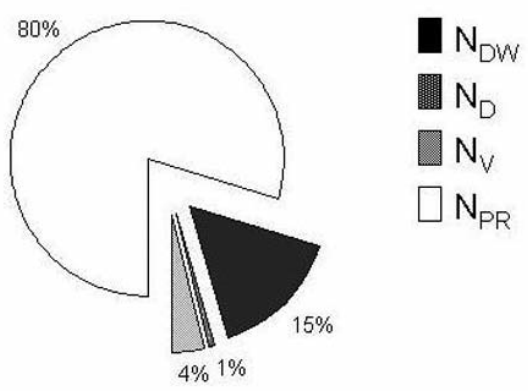

Figure 4. Nitrogen balance components percentage (mean values of the studied period): input components (a), output components (b). 
pied 0.5 ha per crop. Sorghum, sunflowers, wheat and sugar beet required a high fertilizer regime too, namely $100-150 \mathrm{~kg} \mathrm{ha}^{-1}$ of $\mathrm{N}$, usually provided with urea; these amounts were about 2 -times the doses used for organic crops, wheat, barley and sorghum (39-70 $\left.\mathrm{kg} \mathrm{ha}^{-1}\right)$.

\section{Nitrogen balance}

The $\mathrm{N}$ balance for the whole Centonara watershed from 1998-99 to 2004-05 was almost closed (Table 4), with input slightly exceeding output (by $4.4 \mathrm{~kg} \mathrm{ha}^{-1}$ ) in 2000-01 and output slightly exceeding input (by $2.3 \mathrm{~kg} \mathrm{ha}^{-1}$ ) in 2001-02. The t-test computed for the yearly $\Delta \mathrm{N}$ showed that non-significant annual differences were present $(\mathrm{P}<0.01)$.

The $\mathrm{N}$ total input ranged from $28.1 \mathrm{~kg} \mathrm{ha}^{-1}(2002-03)$ to $32.7 \mathrm{~kg} \mathrm{ha}^{-1}$ (1999-00 and 2001-02) (Table 4), which corresponded to $5.5 \mathrm{t}$ and $6.4 \mathrm{t}$ for the whole monitored watershed. The mean percentage of each input balance components are shown in Figure 4a.

$\mathrm{N}_{\mathrm{SF}}$ and $\mathrm{N}_{\mathrm{F}}$ constituted the most substantial inputs, making up more than $60 \%$ of the total input. $\mathrm{N}_{\mathrm{F}}$ decreased significantly $(\mathrm{P}<0.01)$ during the years, thanks to the introduction and diffusion of organic practices, in particular with the cultivation of organic crops (wheat, sorghum and barley): its amount ranged between $8.1 \mathrm{~kg} \mathrm{ha}^{-1}$ (2001-02 and 2003-04) and $15.5 \mathrm{~kg} \mathrm{ha}^{-1}(1999-00)$. The main fertilizers were urea and biammonium phosphate, prevalently distributed during the crop development phase, especially in March and April.

$\mathrm{N}_{\mathrm{SF}}$ depended on the surface cultivated with legumes, alfalfa and field bean. In 1998-99 and 1999-00, when no field beans were cultivated and the alfalfa fields occupied only $12.3 \mathrm{ha}, \mathrm{N}_{\mathrm{SF}}$ was $8.3 \mathrm{~kg} \mathrm{ha}^{-1}$. When in 2004-05 the legume area was almost doubled (21.1 ha), $\mathrm{N}_{\mathrm{SF}}$ increased to $14.3 \mathrm{~kg} \mathrm{ha}^{-1}$. Alfalfa is extremely efficient in this respect: with its $114 \mathrm{~kg} \mathrm{ha}^{-1}$ of nitrogen annually fixed (Vance, 1998), it provided a very relevant $\mathrm{N}$ contribution.

The organic fertilizers applied in the Centonara watershed were mainly biophos ( $4 \%$ of $N)$, organifertil ( $1 \%$ of $N)$, compost $(1 \%$ of $N)$ and, on a few occasions, jolly green $(6 \%$ of $\mathrm{N})$ and geogreen biospecial $(7 \%$ of $\mathrm{N})$. In all the years the contribution of $\mathrm{N}_{0}$ was not very significant, probably because of the low $\mathrm{N}$ content in these fertilizers. Its contribution to the total input ranged between $2 \%$ in $2004-05$ and $11 \%$ in 2001-02, which means an amount of $\mathrm{N}$ between $0.6 \mathrm{~kg} \mathrm{ha}^{-1}$ and $3.7 \mathrm{~kg}$ $\mathrm{ha}^{-1}$. It is important to stress that these low levels of fertilization are a reflection of the low percentage of agricultural area on the total watershed. $\mathrm{N}$ from atmospheric deposition was meanly $7.4 \mathrm{~kg} \mathrm{ha}^{-1}$, corresponding to an annual percentage of $20-30 \%$ of the total $\mathrm{N}$ input. Considering the rural site location and the distance from pollution sources of nitrogen oxides (roads, industrial areas), these amounts were higher than expected. Indeed in the totogen amount a relevant role is played by the $\mathrm{NH}_{4}{ }^{+}$, which derives prevalently from agricultural activity. Its deposition is high and similar to the $\mathrm{NO}_{3}{ }^{-}$, which derives instead from pollutions sources ( 3.7 and $3.4 \mathrm{~kg} \mathrm{ha}^{-1}$ respectively). $\mathrm{NO}_{2}{ }^{-}$ amount was negligible, being meanly $0.3 \mathrm{~kg} \mathrm{ha}^{-1}$. These data were similar to those reported by Jordan and Smith (2005) in agricultural watersheds in Ireland $\left(4.8 \mathrm{NO}_{3}{ }^{-}\right.$and $\left.3.8 \mathrm{NH}_{4}{ }^{+} \mathrm{kg} \mathrm{N} \mathrm{ha}^{-1}\right)$. Finally, because these amounts were almost constant over the years, the few non-significant differences in this input component were caused by the amount of annual precipitation.

The total output ranged between $24.5 \mathrm{~kg} \mathrm{ha}^{-1}$ (1998-99) and $35.0 \mathrm{~kg}$ $\mathrm{ha}^{-1}$ (2001-02) (Table 4), corresponding to $4.8 \mathrm{t}$ and $6.9 \mathrm{t}$ for the total watershed. The percentage of each output balance component is shown in Figure 4b.

$\mathrm{N}_{\mathrm{PR}}$ was the most prevalent output (61-78\% of the total output), proving to be the most efficient method of removing $\mathrm{N}$ from agricultural fields: its contribution ranged between $17.7 \mathrm{~kg} \mathrm{ha}^{-1}$ (2002-03) and 25.6 $\mathrm{kg} \mathrm{ha}^{-1}$ (2001-02). Differences between years were found to be significant $(\mathrm{P}<0.05)$ and reflected the different land use and crop rotations. a)

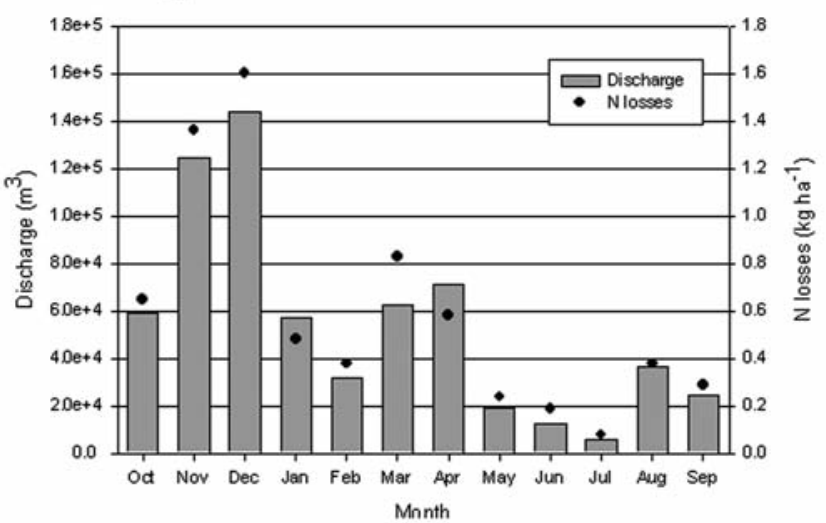

b)

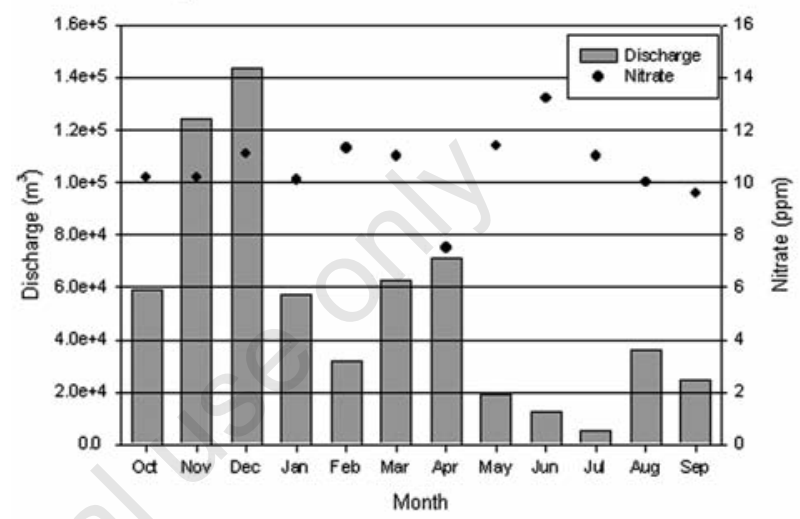

Figure 5. Monthly discharge $\left(\mathrm{m}^{3}\right)$ with monthly mean nitrogen losses $\left(\mathrm{kg} \mathrm{ha}^{-1}\right)$ (a), and with monthly mean nitrate concentration (ppm) (b).

The nitrogen losses in the Centonara stream, $\mathrm{N}_{\mathrm{DW}}$, ranged between $3 \mathrm{~kg}$ $\mathrm{ha}^{-1}$ in 1998-99 and $9.5 \mathrm{~kg} \mathrm{ha}^{-1}$ in 2002-03, and was always less than $33 \%$ of the output computed. As shown in Figure 5a, the highest mean monthly losses were in November and December, corresponding to the highest discharge of the stream. In addition, the $\mathrm{NO}_{3}{ }^{-}$concentration never exceeded the maximum limit permitted by the EU Nitrate Directive (50 ppm of $\mathrm{NO}_{3}^{-}$) and it was not subject to large fluctuation, ranging between $7.5 \mathrm{ppm}$ in April and $13.2 \mathrm{ppm}$ in June (Figure 5b). Finally, to complete the output components, $\mathrm{N}_{\mathrm{V}}$ and $\mathrm{N}_{\mathrm{D}}$ were estimated. Based on conversion factors, the $\mathrm{N}_{\mathrm{V}}$ from urea and biammonium phosphate was estimated between $1.1 \mathrm{~kg} \mathrm{ha}^{-1}$ in 2004-05 and $2.1 \mathrm{~kg} \mathrm{ha}^{-1}$ in both 1999-00 and 2001-02, which means $3-6 \%$ of the total output. Considering $\mathrm{N}_{\mathrm{D}}$ as almost $4 \%$ of the fertilizers, its value ranged between 0.3 and $0.6 \mathrm{~kg} \mathrm{ha}^{-1}$.

\section{Factors correlated with the nitrogen balance}

All N balance components were analyzed using the Pearson correlation matrix. This statistical analysis can help to understand if some components are prevalent in determining the nitrogen balance and if correlations between factors involved in the process existed. Beside the balance components, rainfall volume (P), annual discharge (D), percentage of legumes on the total cultivated area (L/C) and in the total watershed $(\mathrm{L} / \mathrm{W})$, percentage of organic crops $(0 / \mathrm{W})$ and percentage of cultivated area on the total watershed (C/W) were also considered. The significant and more interesting Pearson correlations are shown in Table 5. The sign indicates if the correlation is positive (+) or negative 
(-). Concerning the balance components, $\Delta \mathrm{N}$ showed a highly significant correlation with the $\mathrm{N}_{\mathrm{DW}}(\mathrm{r}=-0.75)$ and significant correlations with $\mathrm{N}_{\mathrm{F}}, \mathrm{N}_{\mathrm{SF}}, \mathrm{N}_{\mathrm{AD}}, \mathrm{N}_{\mathrm{PR}}(\mathrm{r}=0.60, \mathrm{r}=-0.56, \mathrm{r}=-0.50, \mathrm{r}=-0.62)$, indicating that all these terms were important in the final $\mathrm{N}$ balance but they influenced the budget with the same weight. On the other hand, $\Delta \mathrm{N}$ presented no correlation with $\mathrm{N}_{0}, \mathrm{~N}_{\mathrm{D}}$ and $\mathrm{N}_{\mathrm{V}}$.

$\Delta \mathrm{N}$ was also correlated with other factors that were supposed to influence its amount. A correlation between $\Delta \mathrm{N}$ and $\mathrm{P}$ was performed to estimate if the two parameters were linked and to highlight the possible effect of rainfall amount on the nitrogen balance. Their significantly negative correlation $(\mathrm{r}=-0.50)$ indicated that increasing precipitation produced a $\Delta \mathrm{N}$ reduction. This relation was probably due firstly to the increase in the amount of nitrogen loss due to runoff and leaching into the drainage water and secondly to the effective scavenging of the pollutant from the atmosphere (Flues et al., 2002).

Further binary correlations showed that $\Delta \mathrm{N}$ was significantly negatively correlated both with $\mathrm{L} / \mathrm{W}(\mathrm{r}=-0.57)$ and $\mathrm{L} / \mathrm{C}(\mathrm{r}=-0.55)$, while $\mathrm{N}_{\mathrm{F}}$ was well correlated with $\mathrm{N}_{\mathrm{SF}}(\mathrm{r}=-0.84)$ and with $\mathrm{L} / \mathrm{W}(\mathrm{r}=-0.85)$. The presence of legumes in the land use produces, as cascades, evident effects on nitrogen balance, acting directly on the two main inputs, $\mathrm{N}$ symbiotic fixation and fertilization. Dedicating part of the arable area to legumes means reducing fertilizer application and increasing the nitrogen in the soil.

As expected, we found a good correlation between $\mathrm{N}_{0}$ and $\mathrm{O} / \mathrm{W}$ $(\mathrm{r}=0.93)$, because on organic cultivations no inorganic fertilizations are applied. Both $\mathrm{N}_{0}$ and $\mathrm{N}_{\mathrm{F}}$ were significantly correlated with the $\mathrm{N}_{\mathrm{V}}$ $(r=0.77$ and $r=0.54)$, while they were not correlated with $\mathrm{N}_{\mathrm{AD}}$, suggesting that air composition depends not only on agricultural activities but also on the proximity to nitrates oxides sources, such as motor vehicles and industries, which in our watershed are several kilometers away from the monitoring station.

Finally, $\mathrm{N}_{\mathrm{DW}}$ was not correlated with $\mathrm{N}_{\mathrm{F}}$, but was well correlated with $\mathrm{L} / \mathrm{C}$ and $\mathrm{L} / \mathrm{W}(\mathrm{r}=0.65, \mathrm{r}=0.68)$.

\section{Grain yield and nitrogen fertilizer-use efficiency}

The $\mathrm{N}$ losses, and consequently the $\mathrm{N}$ balance, mostly depend on the $\mathrm{N}$ fertilizer-use efficiency of each crop. A crop with a high fertilizer-use efficiency provides positive results in terms of grain yield and environmental safeguard: plants benefit from the nitrogen fertilizer by producing high yields while the asynchrony between $\mathrm{N}$ supply and $\mathrm{N}$ uptake by crops, often due to excessive nitrogen application, is reduced, determining low $\mathrm{N}$ losses from arable fields. Thus, the $\mathrm{N}$ fertilizer-use efficiency also provides an indication of the capacity of the plant to benefit from the management applied and to adapt to a particular pedo-climatic condition.

For this study, the $\mathrm{N}$ fertilizer-use efficiency index ( $\mathrm{kg} \mathrm{N} / \mathrm{kg} \mathrm{N})$, suggested by Fixen and West (2002) and applied by Bao et al. (2006), was computed. It is defined as the amount of grain produced per unit of $\mathrm{N}$ fertilizer applied. It was calculated dividing the $\mathrm{N}$ contained in the final harvested product $(\mathrm{kg})$ per its fertilization, inorganic and organic, $(\mathrm{kg})$, where the $\mathrm{N}$ in harvested products was obtained by the $\mathrm{N}$ plant removal and the grain yield. When the index value is higher than 1 , the crop has an elevated $\mathrm{N}$ fertilizer-use efficiency.

The index was computed only for the cycle-crops with available yield data, such as the main cereals (wheat, barley and sorghum) and other minor crops. Legumes were not considered, because no fertilizers were applied.

Moreover, this index was used to highlight the effect of different types of management on the crop yields: conventional and organic cultivations were compared to evaluate which tillage best suited these pedo-climatic conditions. Organic cultivation, in fact, while reducing the chemical environmental impact, often results in a lower, not economically sustainable grain production.

The results of the mean $\mathrm{N}$ fertilizer-use efficiency, shown in Table 6,
Table 5. Pearson correlation coefficients among factors involved in nitrogen balance.

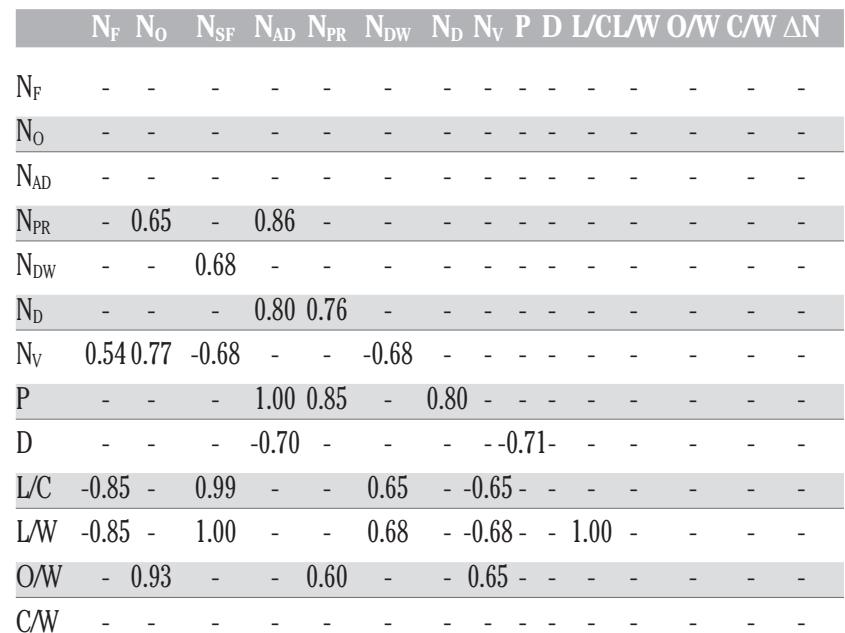

\section{$\Delta \mathrm{N} \quad 0.60 \quad-\quad-0.56-0.50-0.62-0.75 \quad-\quad-0.50-0.55-0.57$}

P, precipitation; D, discharge; L/C, percentage of area legume cultivated / total area cultivated; L/W, percentage of area legume cultivated / total area of watershed; $\mathrm{O} / \mathrm{W}$, percentage of area organically cultivated / total area of watershed; $\mathrm{C} / \mathrm{W}$, percentage of arable area / total area of watershed.

Table 6. Grain yield and N fertilizer-use efficiency.

\begin{tabular}{|c|c|c|c|c|c|}
\hline Crop & 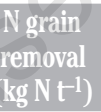 & $\begin{array}{c}\text { GY } \\
\left(\mathrm{tha}^{-1}\right)\end{array}$ & $\begin{array}{l}\mathrm{N} \text { GY } \\
\left.\mathrm{kg} \mathrm{N}^{-1}\right)\end{array}$ & $\begin{array}{c}\text { N Fert } \\
\left(\mathrm{kg} \mathrm{Nha}^{-1}\right)\end{array}$ & $\begin{array}{l}\text { N Fertilizer-use } \\
\text { efficiency index } \\
\text { (GY kg N Fert kg N) }\end{array}$ \\
\hline Barley & 18 & 5.0 & 90.0 & 60.0 & 1.5 \\
\hline Organic barley & 18 & 3.5 & 63.0 & 47.3 & 1.3 \\
\hline Wheat & 23 & 4.8 & 110.4 & 105.8 & 1.0 \\
\hline Organic wheat & 23 & 3.2 & 73.6 & 49.7 & 1.5 \\
\hline Sorghum & 15 & 7.0 & 105.0 & 150.0 & 0.7 \\
\hline Organic sorghum & 15 & 5.0 & 75.0 & 50.0 & 1.5 \\
\hline Corn & 18 & 7.0 & 126.0 & 250.0 & 0.5 \\
\hline
\end{tabular}

GY, grain yield; $\mathrm{N} \mathrm{G}$, nitrogen contained in grain; $\mathrm{N}$ Fert, nitrogen fertilization (inorganic + organic)

indicate that, in the studied pedo-climatic conditions, apart from sorghum and corn, all the cultivated cereals had an index higher than 1 , which means a good $\mathrm{N}$ fertilizer-use efficiency. Corn resulted to be the less efficient crop (0.5), probably due to its elevate fertilization rate $\left(250 \mathrm{~kg} \mathrm{ha}^{-1}\right)$. This will suggest a reduction of the applied quantities.

The comparison between the same crop with diverse management show various results: the sorghum is the crop with the most different efficiency, with an index of the organic crop more than double than the conventional. Organic wheat also had a $\mathrm{N}$ fertilizer-use efficiency higher than the conventional one, but with a low grain yield $\left(4.8 \mathrm{t} \mathrm{ha}^{-1}\right.$ conventional wheat and $3.2 \mathrm{tha}^{-1}$ ), while almost no differences were found between the two kind of barley cultivations.

The purpose of this index determination is to provide information on the $\mathrm{N}$ fertilizer-use efficiency of the crops cultivated in the Centonara watershed, linked to their grain production. It is clear, that this is a simplification of an extremely complex and articulate process. Nitrogen inputs, as seen from the formula of the $\mathrm{N}$ balance, are in fact various and should be considered along with fertilization. Moreover other important factors including the effectiveness of translocation of nitrogen in the grain or the influence of the annual pluviometric regime on the grain yield are not considered. The index, though, is useful to make comparison among crops in the same environment and time, and to decide which crop or which agronomic management is advisable. 


\section{Discussion}

\section{Nitrogen balance}

The total input and output of the Centonara watershed were of the same magnitude, indicating that the crop management attained a good level of ecological sustainability

The excess or surplus $\mathrm{N}$ was probably stored in the soil, in organic or mineral forms or was due to the uncertainties on the data, which were not directly measured. The low $\mathrm{N}$ surplus indicates that the nitrogen that can potentially be lost to groundwater and surface waters was little and consequentially the Centonara stream was always not polluted. Moreover, the non-significant annual differences, computed with the ttest, demonstrated that the effects of land use and management variability throughout the trial were well balanced and did not influence the ecological sustainability of the watershed.

The literature shows a large variability of results: in most agricultural watersheds the $\mathrm{N}$ balance was positive with $\mathrm{N}$ surplus ranging between $27 \mathrm{~kg} \mathrm{ha}^{-1}$ and $117 \mathrm{~kg} \mathrm{ha}^{-1}$ (Isidoro et al., 2006, Bechmann et al., 1998, David et al., 1997), while in an Italian case $\mathrm{N}$ balance gave a slight $\mathrm{N}$ deficit, $-7.7 \mathrm{~kg} \mathrm{ha}^{-1}$ (Ventura et al., 2008). Unfortunately, in this kind of study, caution should be used in comparing literature results, because of the differences in the pedo-climatic conditions, land use and management that are typical of each watershed and determine the final result. Additionally, the comparison of this study at watershed scale with the national nitrogen balance, $37 \mathrm{~kg} \mathrm{ha}^{-1}$, calculated by the EEA in 2000 (OECD, 2003), revealed that this local experience did not reflect the national situation. This result could be explained by the fact that arable land, which is the main source of nitrogen input, constituted only $30 \%$ of the total area of the watershed and, within the cultivated areas, intensive agriculture was only partially applied, and, on the contrary, part of the fields was reserved for organic crops, with low nitrogen input. Therefore, the $\mathrm{N}$ surplus was probably kept in check by the combined effects of several factors, such as the non-intensive agriculture, the presence of organic crops, rotations with legumes, and the presence of vegetation buffers (herbaceous species, bushes and trees in riparian strips). Finally, although $\mathrm{N}$ removed by plants exceeded fertilization input at watershed scale, the Centonara water presented a certain concentration of nitrogen, even if little. This could be due to an asynchrony between $\mathrm{N}$ supply and $\mathrm{N}$ uptake by the crops (Ventura et al., 2008 and Vagstad et al. 2000) or, considering the correct management of the farmers of the watershed, more probably it was linked to the soil characteristic and pluviometric regime of the site.

\section{Preserving the watershed eco-sustainability}

In this research, several strategies to preserve the eco-sustainability of a semi-agricultural watershed and to reduce the risk due to an uncorrected management of arable land are emphasized.

In Centonara watershed, cultivated only for about the $30 \%$ of the total surface, the arable lands have the main role in generating risk for the environment. In fact, in the area covered with spontaneous vegetation the $\mathrm{N}$ cycle can be considered closed, without production of $\mathrm{N}$ deficit or surplus, while the area covered with badlands contributes in the total $\mathrm{N}$ balance only for the $\mathrm{N}$ deriving from atmospheric deposition that, due to the elevate slopes, runoff on the soil instead of infiltrating. Consequently, the global good result of the Centonara watershed derives prevalently from a correct management by the farmers, which during agricultural activity take in account of the main Good Agricultural Practices, such as a limited application of fertilizers, both inorganic and organic, the cultivation of organic crops, the application of crop rotations comprehending legumes, the use of crops with high $\mathrm{N}$ fertilizer-use efficiency and the maintaining of buffer areas of spontaneous vegetation interposed between croplands and surface water bod- ies, which allow the abatement of excess of nitrogen thanks to their buffer effect (Passoni and Borin, 2008, Schoonover and Williard, 2003, Haycock and Pinay, 1993). This will guarantee the safeguard of the environmental of the watershed.

\section{Conclusions}

In a basin such as the Centonara watershed, constituted by natural areas and cultivated fields, the agricultural activity plays a fundamental role in determining the nitrogen balance, since its main components are linked to agricultural practices, such as the management and, more especially, to fertilizer use and crop rotation.

The almost close nitrogen balance indicated that the Centonara watershed could be defined ecologically sustainable. This good result is probably due to several factors, such as non-intensive agriculture, the presence of organic crops, rotations with legumes, and the presence of vegetation buffers. These correct management practices also result in a good quality of the drainage water throughout the year, with the nitrate concentration in the Centonara stream always below the EU limits fixed for water potability (50 ppm).

Despite the annual variability in the watershed land use, the main source of $\mathrm{N}$ input was almost always the biological fixation operated by the legumes, on average $38 \%$ of the total input, followed by the inorganic fertilizer, $33 \%$ of the total input, while most of the nitrogen left the system with the harvest. The percentage of the plant removal component within the total output was $70 \%$.

Finally, the study revealed that the $\mathrm{N}$-fertilizer use efficiency index could be a useful tool to identify ways of producing better crops or improving management in a determined area.

In conclusion, eco-sustainability and the safeguard of the quality of soil and water resources can be achieved by following the Good Agricultural Practices, which comprehend the optimization of chemical inputs such as organic cultivation, rotation with legumes and cropping cereals with high $\mathrm{N}$-use efficiency, and avoiding crops which need higher amounts of nitrogen and produce low yields.

\section{References}

Addiscott T.M., Whitemore A.P., Powlson D.S., 1991. Farming fertilizers and the nitrate problem. CAB International Publ., Wallingford, UK.

Antonioli N., Cazzola M., 1999. Servizio Parchi e Riserve Emilia Romagna, Gessi Bolognesi e Calanchi dell'Abbadessa, Collana Aree Protette dell'Emilia Romagna. Compositori Publ., Bologna, Italy.

Arcara P.G., Gamba C., Bidini D., Marchetti R., 1999. The effect of urea and pig slurry fertilization on denitrification, direct nitrous oxide emission, volatile fatty acids, water-soluble carbon and anthronereactive carbon in maize-cropped soil from the Po plain (Modena, Italy). Biol. Fert. Soils 29:270-276.

Balestrini R., Galli L., Tartari G., 2000. Wet and dry atmospheric deposition at prealpine and alpine sites in northern Italy. Atmosph. Environ. 34:1455-1470.

Bao X., Watanabe M., Wang Q., Hayashi S., Liu J., 2006. Nitrogen budgets of agricultural fields of the Changjiang river basin from 1980 to 1990. Sci. Tot. Environ. 363:136-148.

Bechmann M., Eggestad H.O., Vagstad N. 1998. Nitrogen balances and leaching in four agricultural catchments in southern Norway. Environ. Pollut. 102:493-499.

Beaudoin N., Saad J.K., Van Laethem C., Machet J.M., Maucorps J., Mary B. 2005. Nitrate leaching in intensive agriculture in Northern France: Effect of farming practices, soils and crop rotations. Agr. 
Ecosyst. Environ. 111:292-310.

Burkart M.R., James D.E. 1999. Agricultural-Nitrogen Contributions to Hypoxia in the Gulf of Mexico. J. Environ. Qual. 28:850-859.

David M.B., Gentry L.E., Kovacic D.A., Smith K.M. 1997. Nitrogen balance in and export from an agricultural watershed. J. Environ. Qual. 26:1038-1048.

Farabegoli E., Rossi P., Costantini B., Gardi C., 1994. Cartografia tematica per lo studio dell'erosione a scala di bacino. Riv. Agron. 28:371383.

Fixen P.E., West F.B., 2002. Nitrogen fertilizers: meeting contemporany challenges. Ambio 31:169-76.

Flues M., Hama P., Lemes M.J.L., Dantas E.S.K., Fornaro A., 2002. Evaluation of the rainwater acidity of a rural region due to a coalfired power plant ion Brazil. Atmosph. Environ. 36:2397-2404.

Gamba C., Arcara P.G., Giordani G., Guermandi M., 1998. Influence of manure and cow slurry fertilizers on gaseous losses (N20) in maize cultivated plots on the Po river plain (Bologna, Italy). Agr. Med. 128:157-164.

Howarth R.W., Billen G., Swaney D., Townsend A., Jaworsky N., Lajtha K., 1996. Regional nitrogen budget and riverine $\mathrm{N}$ and $\mathrm{P}$ fluxes for the drainages to North Atlantic Ocean: natural and human influences. Biogeochemestry 35:75-139.

Haycock N.E., Pinay G., 1993. Groundwater nitrate dynamics in grass and poplar vegetated riparian buffer strips during the winter. J. Environ. Qual. 22:273-278.

Høgh-Jensen H., Loges R., Jørgensen F.V., Vinther F.P., Jensen E.S., 2004. An empirical model for quantification of symbiotic nitrogen fixation in grass-clover mixtures. Agr. Syst. 82:181-194.

Isidoro D., Quilez D., Aragues R., 2006. Environmental Impact of Irrigation in La Violada District (Spain): II. Nitrogen fertilization and nitrate export patterns in drainage water. J. Environ. Qual. 35:776-785.

Jordan C., Smith R.V., 2005. Methods to predict the agricultural contribution to catchment nitrate loads: designation of nitrate vulnerable zones in Northern Ireland. J. Hydrol. 304:316-329.

Meisinger J.J.,Randall G.W. 1991. Estimating nitrogen budgets for soilcrop systems. In: R.F. Follett, D.R. Keeney and R.M. Cruse (eds.) Managing Nitrogen for Groundwater Quality and Farm Profitability. Soil Science Society of America Publ., Madison, WI, USA, pp. 85-124.

OEDC/EUROSTAT, 2003. Gross Nitrogen Balances. Handbook. December 2003. Available from: http://www.eea.europa.eu/dataand-maps/indicators/gross-nutrient-balance-1

Oenema 0., Kros H., de Vries W., 2003. Approaches and uncertainties in nutrient budgets: implications for nutrient management and environmental policies. Eur. J. Agron. 20:3-16.

Oenema 0., Heinen M., 1999. Uncertainties in nutrient budget due to biases and errors. In: E.M.A Smaling, 0. Oenema and L.O. Fresco (eds.) Nutrient disequilibria in agroecosystems: concepts and case studies. CAB International Publ., Wallingford, UK, pp 75-97.

Passoni M., Borin M., 2008. Efficacy of narrow buffer strips in removing agricultural pollutants in the shallow subsurface water flux from a cultivated field in north-east Italy. Ital. J. Agron. 3:s61-s62.

Pieri L., Bittelli M.,Wu J., Dun S., Flanagan D., Rossi P., Ventura F., Salvatorelli F., 2007. Using the water erosion prediction project (WEPP) model to simulate field observed runoff and erosion in the Apennines Mountain Range, Italy. J. Hydrol 336:84-97.

Pieri L., Matzneller P., Gaspari N., Marotti I., Dinelli G., Rossi P., 2009. Bulk Atmospheric Deposition in the Southern Po Valley (Northern Italy). Water Air Soil Poll. 210:155-169.

Regione Campania. Direttiva tecnica per il piano di utilizzazione agronomica dei reflui zootecnici. DGR 2302/2003. Available from: http://www.sito.regione.campania.it

Regione Lombardia. Direzione agricoltura. Disciplinari di produzione. PSR 2003 Misura F. Available from: http://www.regione.lombardia.it

Puckett L.J., Cowdery T.K., Lorenz D.L., Stoner J.D., 1999. Estimation of nitrate contamination of an agro-ecosystem outwash aquifer using a nitrogen mass-balance budget. J. Environ. Qual. 28:2015-2025.

Schoonover J.E., Williard K.W.J., 2003. Ground water nitrate reduction in giant cane and forest riparian buffer zones. J. Am. Water Resour. As. 39: 347-354.

Tabacco E., Borreani G., Grignao C., 2003. Azotofissazione dell'erba medica e del trifoglio pratense stimata con il metodo dell'isotopo 15N nella Pianura Padana occidentale. Riv. Agron. 37:93-97.

Vagstad N., Jansons V., Loigu E., Deelstra J., 2000. Nutrient losses from agricultural areas in the Gulf of Riga drainage basin. Ecol. Eng.14:435-441.

Vance C.P. 1998. Legume symbiotic nitrogen fixation: agronomic aspects. In: H.P. Spaink, A. Kondorosi and P.J.J. Hooykaas (eds.) The Rhizobiaceae. Kluwer Academic Publi., Dortrecht, The Netherlands, pp 509-530.

Ventura F., Rossi P., Vicari A., 2004. Effect of land use on soil erosion in a small watershed of Emilia-Romagna Region. Ital. J. Agron. 8:2936 .

Ventura M., Scandellari F., Ventura F., Guzzon B., Rossi Pisa P., Tagliavini M. 2008. Nitrogen balance and losses through drainage waters in an agricultural watershed of the Po Valley (Italy). Eur. J. Agron. 29:108-115.

Watson C.A., Atkinson D., 1999. Using nitrogen budget to indicate nitrogen use efficiency and losses from whole farming system: a comparison of three methodological approaches. Nutr. Cycl. Agroecosys. 53:259-267.

Zalidis G., Stamatiadis S., Takavakoglou V., Eskridge K., Misopolinos N., 2002. Impact of agricultural practices on soil and water quality in the Mediterranean region and proposed assessment methodology. Agr. Ecosyst. Environ. 88:137-146. 